\title{
Analysis of Phytoplankton Structure Community, Water Quality and Cultivation Performance in Litopenaeus vannamei Intensive Pond Located in Tembokrejo Village, Muncar, Banyuwangi
}

\author{
Gesang Maulana Dwi Katmoko ${ }^{1}$, Yenny Risjani ${ }^{1}$, Endang Dewi Masithah ${ }^{2}$ \\ ${ }^{1}$ Study Program of Aquaculture, Faculty of Fisheries and Marine Sciences, University of Brawijaya, Malang, Indonesia \\ ${ }^{2}$ Study Program of Aquaculture, Faculty of Fisheries and Marine Sciences, Airlangga University, Surabaya, Indonesia
}

\begin{abstract}
Phytoplankton plays an important role in Litopenaeus vannamei cultivation. It plays a role as natural feed, water quality control, and indicator of shrimp cultivation success. The community structure of phytoplankton can be influenced by organic matter concentration in ponds. On the other hand, water quality and phytoplankton community structure also influence the productivity of shrimp cultivation. The research aimed to analyze the phytoplankton structure community, cultivation performance and the water quality in one of vananmei shrimp cultivation located in Muncar District. The research used the descriptive method. The research was conducted in two shrimp intensive system ponds in Tembokrejo Village, Muncar District, Banyuwangi, on February-March 2020. Parameters observed were composition, diversity, and density of phytoplankton, water quality parameters, and production performance in each pond. Based on the results, five phytoplankton classes was found: Bacillariophyceae (12 genera), Chlorophyceae (4 genera), Cyanophyceae (8 genera), Dinophyceae (2 genera), and Euglenophyceae (1 genus). Based on the density, Cyclotella and Chlorella were dominated in both ponds. Diversity index values on ponds 1 and ponds 2 were 1.64 and 1.71, respectively. The productivity of both ponds was 10.794 kg.ha-1 and 11.698 kg.ha-1, FCR (Feed Conversion Ratio) were 0.99 and 1.18, and ADG (Average Daily Growth) on both ponds were 0.16 g.day ${ }^{-1}$. Water quality parameters in both ponds showed an optimal range for vannamei cultivation, except phosphate, which is quite high. Overall, the cultivation performance of both ponds in our research showed good results. However, cultivation performance obtained in this research was not on its best performance yet due to Infectious Myonecrosis (IMNV) infection.
\end{abstract}

Keywords: Cultivation performance, Litopenaeus vannamei, muncar, phytoplankton.

\section{INTRODUCTION}

The cultivation performance of vannamei (Litopenaeus vannamei) currently increases. Based on data, vannamei cultivation contributed as much as $53 \%$ of total crustacean production in the world [1]. In addition, vannamei shrimp also has various advantages compared to other types of shrimp. The advantages comprised the fry quality of shrimp are easy to obtain, having high survival rate, can be cultivated in ponds with high stocking densities, more resistant to disease, short cultivation cycle, and has low feed conversion [2]. The species has become an object for studies to increase their immune system against vibriosis [3].

Muncar, a district in Banyuwangi Regency, is one of the main vannamei production districts located in East Java. Muncar is also the center of the fish processing industry in Indonesia. Although it has many positives impacts on improving the economy, the existence of these industries also brings a negative impact on the environment, especially the aquatic

\footnotetext{
* Correspondence address:

Gesang Maulana Dwi Katmoko

Email : gmaulana45@student.ub.ac.id

Address : Faculty of Fisheries and Marine Science, University of Brawijaya, Veteran, Malang, 65145
}

environment. A previous study mentioned that the industry activity in Muncar produced around $14,300 \mathrm{~m}^{3}$ of waste per day [4]. These wastes are organic waste which can cause pollution in the waters.

Meanwhile, shrimp ponds around these industries use seawater around the coast of Muncar as a medium for vannamei shrimp cultivation. In addition, intensification in vannamei cultivation also causes various problems. The high stocking densities and the increase of feed given lead to the increasing in organic matter content in shrimp ponds and then followed by increasing in shrimp excretion and feed residue.

The excretion and feed residue in the water can be a source of organic matter and nitrogen (N). About $80 \%$ of the nitrogen entered the pond will be wasted and suspended [5]. It will lead to nutrient enrichment or also called eutrophication. Eutrophication can affect the structure of the phytoplankton community. Eutrophication is an abnormal condition in waters characterized by high levels of nutrients contained in water that exceed normal limits. Eutrophication conditions and high water temperature due to global warming will cause Harmful Algal Blooms (HABs). In addition, 
nutrient content will also affect the diversity and density of phytoplankton in the waters.

Although Indonesian archipelago has the highest biodiversity of phytoplankton, like marine [6], the study related to their role in brackish water ponds is needed to be explored. Phytoplankton in shrimp pond ecosystems has an important role in supporting the success of the cultivation. Generally, phytoplankton occurs naturally in all shrimp ponds. The existence of phytoplankton provides benefits both directly and indirectly for cultivation productivity. A previous study argued that the type of phytoplankton growth in shrimp pond ecosystems affects productivity [7]. Therefore, this study aimed to analyze the phytoplankton community structure, water quality parameters, and cultivation performance in one of the vannamei cultivation ponds in Tembokrejo Village, Muncar District, Banyuwangi regency.

\section{MATERIAL AND METHOD \\ Sample collection}

The research was conducted from February to March 2020 in one of the vannamei shrimp farming locations located in Tembokrejo Village, Muncar District, Banyuwangi Regency. The number of ponds observed was two ponds (pond 1 and pond 2), which were randomly selected. The parameters observed in this study were the phytoplankton community structure consisting of the composition, diversity, and density of phytoplankton. The productivity performance parameters observed were productivity, Survival Rate (SR), Feed Conversion Ratio (FCR), and Average Daily Growth (ADG). Water quality parameters observed were temperature, water transparency (WT), dissolved oxygen, $\mathrm{pH}$, nitrate, nitrite, ammonia, and phosphate.

Phytoplankton samples were sampled every day during the study at 1 PM. Sampling was carried out at four stations using a $5 \mathrm{~L}$ volume bucket with two repetitions at each station. The water sample was filtered using a plankton net of $25 \mu$ size and put into a $20 \mathrm{~mL}$ film bottle. Then, $1 \%$ Lugol's iodine solution was added to keep the sample from being damaged. Samples were given the label as a marker and stored in a cool box for later identification at the Jatisari 2 Laboratory located in Bomo Village, Blimbingsari District, Banyuwangi Regency.

Phytoplankton samples were observed under a binocular microscope with a magnification of 400X. Phytoplankton calculations using a hemocytometer with counted with hand tally counter. The calculation of phytoplankton densities uses the following method [6].

$$
P D=\left(\frac{n A+n B+n C+n D}{4}\right) \times 10,000
$$

\section{Description:}

$\mathrm{PD}=$ Phytoplankton Density

$n A, n B, n C$, and $n D=$ Number of cells count in block $A, B, C$ and $\mathrm{D}$

$4=$ Number of block count;

$10,000=$ The volume of Haemocytometer Big Block

A diversity index is calculated using the Shannon-Wiener method as follows:

$$
H^{\prime}=\sum_{i=1}^{n} p i \ln p i
$$

Description:

$\mathrm{H}^{\prime}=$ the value of Diversity Index;

$\mathrm{pi}=\mathrm{a}$ number of cells of type $\mathrm{i}(\mathrm{ni})$ divided by the total number of cells in the sample $(\mathrm{N})$.

Cultivation performance parameters observed in both ponds included harvest tonnage (yield/pond area), survival rate (SR), feed conversion ratio (FCR), and average daily growth (ADG). The formula used to measure the SR value is based on [7]:

$$
S R=\frac{N t}{N 0} \times 100 \%
$$

Description:

$\mathrm{SR}=$ survival rate

$\mathrm{Nt}=$ the total number of shrimp harvested

$\mathrm{NO}=$ the number of shrimp stocked.

FCR is calculated using the formula as follows [7]:

$$
F C R=\left(\frac{F}{W-W 0}\right)
$$

\section{Description:}

FCR $=$ feed ratio converted to biomass

$\mathrm{F} \quad=$ the weight of feed consumed $(\mathrm{kg})$

$\mathrm{Wt}=$ shrimp biomass at the end cultivation $(\mathrm{kg})$

WO = the initial weight of shrimp biomass $(\mathrm{kg})$

ADG is calculated using the formula as follows [8]:

$$
A D G=\frac{M B W o-M B W t}{t}
$$

Description:

ADG = the average daily gain of shrimp

MBWo = the average body weight actual sampling

MBWt = the average body weight after sampling

$\mathrm{t} \quad=$ the sampling period

Ponds Temperature, water transparency, $\mathrm{pH}$, salinity, and dissolved oxygen were measured every day during the study. Temperature, water 
transparency, $\mathrm{DO}, \mathrm{pH}$, and salinity were observed twice a day. While, Nitrate, nitrite, ammonium, and phosphate were measured every three days.

\section{RESULT AND DISCUSSION}

\section{Phytoplankton identification}

Based on the results, 27 genera were obtained from five classes of phytoplankton in both ponds. The phytoplankton genera obtained can be seen in Table 1.

Based on Table 2, it can be shown that both ponds have almost the same genera, but the second pond has more diverse phytoplankton genera. The genera of phytoplankton found in both ponds are the common phytoplankton found in shrimp ponds. The results from observations of phytoplankton from both ponds during the study were supported by previous research [7] in a vannamei shrimp (L. vannamei) farm in Situbondo, where the genera found were: Oocystis, Chlorella, Nannocloropsis, Chaetoceros, Nitzschia, Coscinodiscus, Cyclotella, and Ulothrix. However, the phytoplankton found in this study had a higher diversity. It can be due to the relatively high nutrient content ( $\mathrm{N}$ and $\mathrm{P}$ ) in our study compared to the previous study so that the diversity is also high. Another previous research explained that phytoplankton requires $\mathrm{N}$ and $\mathrm{P}$ elements in the synthesis of fat and protein [11]. These compounds could only be used directly by phytoplankton if they are in the form of nitrates and orthophosphates. The N:P ratio required by phytoplankton is generally $16: 1$.

\section{Phytoplankton composition}

The percentage of each phytoplankton class found in both ponds can be seen in Figure 1 . Based on the diagram above, the three dominant classes found in both ponds are Bacillario- phyceae, Chlorophyceae, and Cyanophyceae. Dinophyceae and Euglenophyceae were also found, but still in a low percentage. The composition of phytoplankton in pond 1 and pond 2 is relatively the same, but the diversity is different.

Bacillariophyceae is the dominant phytoplankton class among other classes. It can be influenced by the source of cultivation water. According to a previous study [12], Bacillariophyceae or diatoms are the most dominant types of phytoplankton in marine waters. Other previous research also found Diatom dominating in vannamei cultivation located in Bangladesh [13]. In addition, diatoms are a type of phytoplankton that are beneficial for the growth of vannamei shrimp because they can help form carapace in shrimp.

\section{Phytoplankton Density}

The phytoplankton average density observed in both ponds can be seen in Table 1. Based on the Table, Cyclotella from Bacillariophyceae was the highest density phytoplankton. The percentage density of a phytoplankton species in the waters should reach more than $10 \%$ of the total density, for the species can be said to dominate [5].

Chlorella from Chlorophyceae was the second class that dominated in both ponds. Chlorophyceae can be found dominated in water ecosystems with high light intensity [14]. The dominance of phytoplankton in shrimp ponds is strongly influenced by water quality, such as nitrogen and phosphorus. The density values of the Bacillarophycea and Chlorophyceae classes are still quite high. Both genera are types of plankton that are beneficial to shrimp.
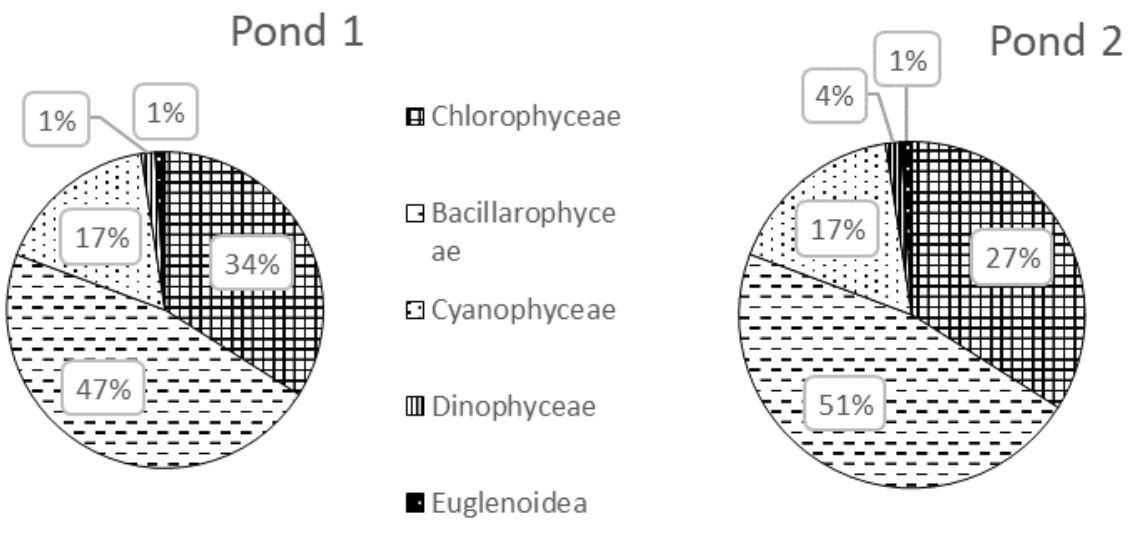

田Chlorophyceae

$\square$ Bacillarophyceae

¿ Cyanophyceae

min Dinophyceae

- Euglenoidea

Figure 1. The percentage of phytoplankton composition in ponds 
Meanwhile, the genera belonging to Cyanophyceae, Dinophyceae, and Euglenophyceae are genera that are quite harmful to cultivated organisms because they can produce toxins that are harmful to aquatic organisms. In the Cyanophyceae class, the most common genera found is Oscillatoria. Oscillatoria is a type of blue-green algae (BGA) that is commonly found in brackish waters. Oscillatoria is a diazotrophic group in Cyanobacteria, where this genus can fix nitrogen gas (N2) from the air so that this type of organism can live in waters that have low nitrogen levels even as long as there is phosphorus [17].

The diversity index value can be seen in Table 1. The diversity index value showed that the diversity value $\mathrm{H}^{\prime}$ of phytoplankton genera in pond 1 and pond 2 were only slightly different. Based on the $\mathrm{H}^{\prime}$ value, both ponds have a moderate diversity index $\left(1<\mathrm{H}^{\prime}<3\right)$, indicating the water ponds are still of good quality to support phytoplankton growth. It was mentioned that the diversity index value $\mathrm{H}^{\prime}$ is greater than 3 , then the diversity of genera is high. If the value of diversity $\mathrm{H}^{\prime}$ is between 1 and 3 , then the diversity of genera is moderate, and if the diversity value $\mathrm{H}^{\prime}$ is less than 1 , indicated that the water ecosystem has low genera diversity [18].

\section{Cultivation Performance Productivity}

The cultivation performance parameters of both ponds can be seen in Table 2 . The productivity in pond 2 was higher than in pond 1. It can be influenced by the amount of stocking density, feed management, water quality. The productivity of cultivation was also influenced by the length of the cultivation day. The longer cultivation day can result in higher yields. The existence of phytoplankton is also a supporting factor. Besides its role as natural food which is useful for the formation of the carapace in shrimp, several types of diatoms can produce some toxins which have a negative impact on aquatic organisms.

Table 2. Cultivation Performance of Both Ponds

\begin{tabular}{llll}
\hline No & Indicator & P1 & P2 \\
\hline 1 & Day of Culture (DOC) & 62 & 64 \\
2 & Productivity (kg.ha $\left.{ }^{-1}\right)$ & 10,794 & 11,698 \\
3 & Survival Rate (\%) & 95 & 97 \\
4 & FCR & 0.99 & 1.18 \\
5 & ADG $\left(\right.$ g.day $^{-1}$ ) & 0.16 & 0.16 \\
\hline
\end{tabular}

Table 1. The Average of Phytoplankton Density of Both Ponds

\begin{tabular}{|c|c|c|c|}
\hline Class & Genera & Pond 1 & Pond 2 \\
\hline \multirow{4}{*}{ Chlorophyceae } & Chlorella & 31,000 & 28,611 \\
\hline & Cosmarium & 800 & 833 \\
\hline & Oocystis & 3,100 & 3,519 \\
\hline & Gleocystis & 1,800 & 5,278 \\
\hline \multirow{12}{*}{ Bacillarophyeae } & Skeletonema & 7,500 & 7,037 \\
\hline & Cyclotella & 31,400 & 42,222 \\
\hline & Nitzschia & 1,200 & 1,944 \\
\hline & Coscinodiscus & 6,200 & 11,389 \\
\hline & Dithylium & 1,900 & 370 \\
\hline & Navicula & 1,200 & 2,870 \\
\hline & Amphiphora & 1,000 & 463 \\
\hline & Biduplhia & 200 & 741 \\
\hline & Chaetoceros & 2,800 & 22,22 \\
\hline & Melosira & 1,000 & 185 \\
\hline & Amphora & - & 1,574 \\
\hline & Cerataulina & - & 3,981 \\
\hline \multirow{8}{*}{ Cyanophyceae } & Microcystis & 5,400 & 2,500 \\
\hline & Chrococcus & 4,400 & 10,926 \\
\hline & Oscillatoria & 11,700 & 926 \\
\hline & Gleocapsa & - & 28,611 \\
\hline & Anabaena & 2,900 & 2,778 \\
\hline & Pseudoanabaena & - & 556 \\
\hline & Anabaenopsis & - & 463 \\
\hline & Merismopedia & - & 1,944 \\
\hline \multirow{2}{*}{ Dinophyceae } & Protoperidinium & 1,400 & 2,407 \\
\hline & Alexandrium & 500 & 3,981 \\
\hline \multirow[t]{3}{*}{ Euglenophyceae } & Euglena & 1,250 & 1,574 \\
\hline & Total & 118,650 & 141,296 \\
\hline & Wierner Index & 1.64 & 1.71 \\
\hline
\end{tabular}




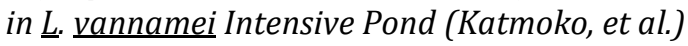

The productivity on Pond 2 showed a higher value than on pond 1 . The differences of these values were might due to the higher density of Bacillariophyceae and Chlorophyceae in Pond 2 than Pond 1 . We argued that the availability of natural food in pond 2 was higher than in pond 1 , so shrimp obtain more nutrient sources due to the phytoplankton. Bacillariophyceae and Chlorophyceae are good natural food for vannamei shrimp due to these high nutrients. Microalgae contain b-carotene and chlorophyll content increase the antioxidant pigment astaxanthin in shrimp tissue, which leads to an increase in the growth of the shrimp [19].

In contrast, when viewed from the adverse phytoplankton types, the density of Microcystis, Chrococcus, Oscillatoria, and Anabaena was found to be higher in pond 1 . These types of phytoplankton can produce cyanotoxins. Cyanobacteria have an important role as the main oxygen producer in waters [20]. However, its ability to adapt causes cyanobacteria to grow rapidly. It cause various negative impacts on the waters, such as changing water color, decreasing water quality, and causing an unpleasant taste in the meat of cultivated organisms due to the production of geosmin and methyl iso-borneol (MIB), which can result in decreased quality of aquaculture products. Oscillatoria, as one of the many phytoplankton found, could also cause negative impacts if the density is uncontrolled. Oscillatoria can produce toxin compounds such as neurotoxins, anatoxins, and hepatotoxins [21].

\section{Survival Rate}

The survival rate in ponds 1 and 2 was 95\% and $97 \%$, respectively. The survival rate in both ponds is quite high. In previous research [22], the survival rate obtained ranges from $88-91 \%$. When compared with the survival rate in this study, the survival value in both ponds has a higher value. It is because the harvesting in both ponds was carried out quickly before the IMNV virus spreads and increased shrimp mortality.

Phytoplankton also may affect the survival rate in shrimp ponds. The types of phytoplankton dominated were Bacillariophyceae and Chlorophyceae. These types of phytoplankton play a role as a natural food that contained high nutrients so that it can support the growth, development, and immune response of vannamei shrimp. Microalgae contain b-carotene and vitamin $C$ compounds which can improve the health condition of shrimp [17]. Our result is supported by previous research, which showed the pond dominated by phytoplankton Nanocloropsis and Chlorella from Chlorophyceae class and Navicula from the Bacillariophyceae class that showed a higher survival rate than the control pond, which was dominated by phytoplankton genera of Cyanophyceae [21]. The survival rate can also be influenced by the stocking density at the beginning of cultivation. A previous study mentioned the optimal stocking density in the intensive system of vannamei shrimp cultivation is 100 fish. $\mathrm{m}^{-2}$ [20]. Based on another research, vannamei shrimp reared at a density of 100 ind. $\mathrm{m}^{-2}$ showed a better survival rate and growth [22].

\section{Feed Conversion Ratio (FCR)}

The FCR value in ponds 1 and 2 was 0.99 and 1.18, respectively. The FCR value in both ponds was considered good. The good FCR value in shrimp culture is 1.37-1.66 [3]. The FCR value indicates the level of performance of shrimp in converting feed to yields. FCR is a comparison between the feed consumed and the biomass produced, thus the lower the FCR indicate the better performance of the shrimp in converting feed into biomass [23].

The FCR value in pond 1 was lower than pond 2 , indicating the shrimp reared in pond 1 had a better performance in converting feed to yields than pond 2. It may be influenced due to the differences in stocking density in both ponds. The stocking density applied to pond 1 was lower than that of pond 2 . It is consistent with the results of previous research [24], which explained that the lowest FCR value was obtained in the vannamei shrimp reared on the medium with the lowest stocking density. The lower stocking density results in a lower level of competition in feed utilization, thus the shrimp cultivated in pond 1 could more utilize the feed given. In addition, it can also be seen that the density of phytoplankton from the Dinophyceae class in pond 2 is higher than pond 1 . Dinophyceae is able to produce some toxins that cause damage to the organism's cells [25]. It may be assumed that the digestive tract cells of shrimp in pond 2 had a disturbance due to these toxins, thus the absorption process of nutrients could not run optimally. Therefore, most farmers prefer their cultivation ponds to be dominated by diatoms and green algae in the phytoplankton community structure.

\section{Average Daily Gain (ADG)}

The average Daily Gain (ADG) value in pond 1 and pond 2 was 0.16 g.day $^{-1}$. The ADG value in 


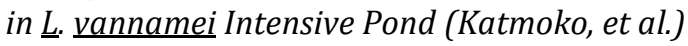

both ponds is still in a good range in the cultivation of vannamei shrimp. The normal ADG value in vannamei shrimp cultivation is 0.22 g.day $^{-1}$ [26]. A research obtained daily growth rate values for vannamei shrimp of $0.12-0.17$ g.day ${ }^{-1}$ [27]. The growth rate of vannamei shrimp can be influenced by several factors such as the volume of water change every day, feed supply, fertilization, aeration, and the composition of the phytoplankton in the pond.

\section{Water Quality Parameters}

The range of average values for the water quality parameters of both ponds can be seen in Table 3. The temperature in both ponds was in optimal conditions for shrimp growth. It is supported by a previous study that stated the optimal temperature value for shrimp growth is in the range of $24-32^{\circ} \mathrm{C}$ [28]. Temperature can influence the metabolism rate of shrimp.

The water transparency in both ponds was classified as good for vannamei shrimp cultivation. The optimal water transparency value in shrimp ponds ranged between $30-45 \mathrm{~cm}$. Pond with water transparency under $30 \mathrm{~cm}$ indicated the content of the suspension or phytoplankton is very dense, thus it needs to be recirculated [29].

DO in both ponds was still in a tolerable range for vannamei shrimp. The optimal DO range for shrimp culture is $3.5-7.5 \mathrm{ppm}$ [28]. Less than 3 ppm DO content can cause shrimp stressed, thus they became susceptible to disease infection, while DO content less than $2 \mathrm{ppm}$ has the potential of death in organisms, including shrimp. Oxygen levels in waters can be influenced by salinity and temperature [31]. The solubility of oxygen will be higher in low-temperature water conditions and will decrease with higher salinity.

The $\mathrm{pH}$ values in both ponds were in the optimal range for the growth of vannamei shrimp. The allowable $\mathrm{pH}$ value limit in shrimp farming is $7.5-8.5$ [32]. However, when viewed from the $\mathrm{pH}$ fluctuation occurred, the $\mathrm{pH}$ fluctuation in pond 2 was higher than in pond 1. The phytoplankton density may influence the $\mathrm{pH}$ fluctuation in the water environment. The higher density of phytoplankton, the greater the $\mathrm{pH}$ fluctuation occurred. However, based on the data obtained, the $\mathrm{pH}$ fluctuation from the beginning to the end of the observation is still in a safe range for vannamei shrimp. A sudden change in $\mathrm{pH}$ value of 1 unit could kill aquatic organisms [33].

The salinity in both ponds was in the optimal range. The ideal salinity range for shrimp culture is 15 to 25 ppt [34]. Lower salinity vale leads to thinning the shrimp shell, while a too high salinity value leads to inhibition of the molting process [35]. Salinity has a significant role in influencing the growth rate, survival, and physiological function of shrimp.

The nitrate concentration in both ponds was in a safe range for cultivating vannamei shrimp. The tolerable nitrate concentration for vannamei shrimp cultivation in ponds is not more than 177 $\mathrm{mg} . \mathrm{L}^{-1}$ [36]. Nitrate is a form of nitrogen which not too dangerous for aquatic organisms, especially vannamei shrimp. However, too high nitrate concentration and the influence of salinity in the waters could be dangerous compounds [37]. Nitrates can be used by phytoplankton to grow and develop [38].

The nitrite concentration in both ponds is in a safe range for cultivating vannamei shrimp. Nitrite toxicity can be influenced by $\mathrm{pH}$ and salinity in the water ecosystem. In vannamei shrimp culture, the tolerable nitrite content is not more than $6.1 \mathrm{mg} . \mathrm{L}^{-1}$ at $15 \mathrm{ppt}$ salinity and no more than $15.2 \mathrm{mg} \cdot \mathrm{L}^{-1}$ at $25 \mathrm{ppt}$ salinity [39]. Excess nitrite content in aquaculture ponds could cause a decrease in appetite, growth, increase oxygen consumption and nitrogen excretion, disrupt hemolymph protein concentrations and increase mortality [40].

Table 3. The Data of Water Quality of Both Ponds

\begin{tabular}{|c|c|c|c|c|c|}
\hline \multirow[t]{2}{*}{ Parameters } & \multicolumn{2}{|c|}{ Pond 1} & \multicolumn{2}{|c|}{ Pond 2} & \multirow[t]{2}{*}{ Optimum Range } \\
\hline & $5 \mathrm{AM}$ & 3 PM & $5 \mathrm{AM}$ & 3 PM & \\
\hline $\mathrm{DO}\left(\mathrm{mg} \cdot \mathrm{L}^{-1}\right)$ & $4.0-4.7$ & $4.9-8.9$ & $3.9-5.1$ & $4.1-8.9$ & $3.5-7.5[30]$ \\
\hline Temperature $\left({ }^{\circ} \mathrm{C}\right)$ & $28-31$ & $29-33$ & $27-31$ & $29-32$ & $24-32[28]$ \\
\hline $\mathrm{pH}$ & 7.1-7.9 & $7.6-8.5$ & $7.1-8.1$ & $7.3-8.3$ & $7.5-8.5[32]$ \\
\hline Sal (g. $\left.\mathrm{L}^{-1}\right)$ & $18-22$ & $18-22$ & $19-23$ & $18-22$ & $15-25[34]$ \\
\hline WT $(\mathrm{cm})$ & $33-42$ & $28-41$ & $32-40$ & $29-37$ & $30-45[29]$ \\
\hline NO2- $\left(\mathrm{mg}^{-\mathrm{L}^{-1}}\right)$ & \multicolumn{2}{|c|}{$0.02-2$} & \multicolumn{2}{|c|}{$0.02-2$} & $<15.2$ [39] \\
\hline NO3- $\left(\mathrm{mg} \cdot \mathrm{L}^{-1}\right)$ & \multicolumn{2}{|c|}{$1-10$} & \multicolumn{2}{|c|}{$1-15$} & $<177[36]$ \\
\hline $\mathrm{NH} 4+\left(\mathrm{mg} \cdot \mathrm{L}^{-1}\right)$ & \multicolumn{2}{|c|}{$0.1-3.2$} & \multicolumn{2}{|c|}{$0.1-3$} & $<5[3]$ \\
\hline PO4-3 (mg.L L $\left.^{-1}\right)$ & \multicolumn{2}{|c|}{$0.5-1.5$} & \multicolumn{2}{|c|}{$0.25-2$} & $0.08-0.28[5]$ \\
\hline $\mathrm{N}: \mathrm{P}$ Ratio & \multicolumn{2}{|c|}{$1.3-16.5: 1$} & \multicolumn{2}{|c|}{$0.6-11.6: 1$} & $16: 1[11]$ \\
\hline
\end{tabular}




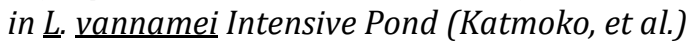

The range between the maximum and minimum phosphate values in pond 2 was higher than in pond 1 . It may be related to the higher FCR value in pond 2 . Higher FCR indicates that the feed given is still left and not utilized by the shrimp. The remaining feed wasted in the waters is a source of phosphate [41]. The phosphate content of both ponds is quite high. Sukadi [42] conducted observations of water quality in shrimp aquaculture ponds in Bangladesh and found a phosphate content of $0.08-0.28 \mathrm{mg} \cdot \mathrm{L}^{-1}$.

Ammonium ranges in both ponds are still in a good range for shrimp growth. A safe level of ammonium concentration for shrimp culture is less than $5 \mathrm{mg} . \mathrm{L}^{-1}[30]$. The ammonium content in water can be regulated by the content of organic matter in the waters. Organic materials such as food waste, organisms, and dead organisms will break down into ammonium. Ammonium is ammonia that ionizes in water.

\section{CONCLUSION}

In conclusion, the phytoplankton community structure in both ponds consisted of 27 genera from five phytoplankton classes with a moderate diversity index $\left(\mathrm{H}^{\prime}\right)$, which Chlorophyceae and Bacillariophyceae were dominated. The physical and chemical parameters of the water quality in both ponds are in the optimal range for vannamei shrimp culture. Overall, the cultivation performance of both ponds in our research showed good results.

\section{ACKNOWLEDGEMENT}

The author thanks to Mr. Ersan as the shrimp farm's owner, Mr. Djito as the shrimp farm technician and Alvian as the shrimp farm technical assistance whose support this research done successfully.

\section{REFERENCES}

[1] Food and Agriculture Organization (FAO). 2018. The state of world fisheries and aquaculture: meeting the sustainable develompment goals. FAO. Rome.

[2] Gunarto, G., H.S. Suwoyo, B.R. Tampangallo. 2012. Budidaya udang vaname pola intensif dengan sistem bioflok di tambak. Jurnal Riset Akuakultur. 7(3). 393-405.

[3] Risjani, Y., N. Mutmainnah, P. Manurung, S. N. Wulan, Yunianta. 2021. Exopolysaccharide from Porphyridium cruentum (purpureum) is not toxic and stimulates immune response against vibriosis: the assessment using zebrafish and white shrimp Litopenaeus vannamei. Mar. Drugs. 19(3): 133.

[4] Priambodo, G., S. Mangkoedihardjo, W. Hadi, E.S. Soedjono. 2011. Wastewater treatment strategy for fish processing industry in Kota Pantai Muncar of Indonesia. Int. J. Acad. Res. 3(2). 93-97.

[5] Zafar, M., M.K. Abbasi, A. Khaliq. 2013. Effect of different phosphorus sources on the growth, yield, energy content and phosphorus utilization efficiency in maize at Rawalakot Azad Jammu and Kashmir, Pakistan. J. Plant Nutr. 36(12). 1915-1934.

[6] Risjani, Y., A Witkowski, A. Kryk, Yunianta, E. Gorecka, M. Krzywda, I. Safitri, A. Sapar, P. Dabek, S. Arsad, E. Gusev,Rudiyansyah, L. Peszek, R. J Wrobel. 2021. Indonesian coral reef habitats reveal exeptionally high species richness and biodiversity of diatom assemblages. Estuarine, Coastal and Shelf Science. 261. 107551.

[7] Arifin, N.B., M. Fakhri, A. Yuniarti, A.M. Hariati. 2017. Phytoplankton community at intensive cultivation system of whiteleg shrimp, Litopenaeus vannamei in Probolinggo, East Java. El-Hayah. 6(3). 7985.

[8] LeGresley, M., G. McDermott. 2010. Metodos microscopicos y moleculares para el analisis cuantitativo del fitoplankton. Exchange Organizational Behavior Teaching Journal. 110.

[9] Effendi, I. 1997. Biologi perikanan. Yayasan Pustaka Nusantara. Yogyakarta.

[10] Haliman, Adijaya. 2005. Pembudidayaan dan prospek prospek pasar udang putih yang tahan penyakit : udang vannamei. Penebar Swadaya. Jakarta. 126.

[11] Mustofa, A. 2015. Kandungan nitrat dan pospat sebagai faktor tingkat kesuburan perairan pantai. Disprotek. 6(1). 13-19.

[12] Fauziah, A., D.G. Bengen, M. Kawaroe, H. Effendi, M. Kristanti. 2018. Spatio-temporal distribution of microalgae producing chlorophyll and carotenoid pigments in Bali Strait, Indonesia. Biodiversitas. 20(1). 61-67.

[13] Casé, M., E.E. Leça, S.N. Leitão, E.E. SantAnna, R. Schwamborn, A.T. de Moraes Junior. 2008. Plankton community as an indicator of water quality in tropical shrimp culture ponds. Mar. Pollut. Bull. 56(7). 1343-1352.

[14] Pratiwi, H., A. Damar, Sulistiono. 2018. Phytoplankton community structure in the 
Estuary of Donan River, Cilacap, Central Java, Indonesia. Biodiversitas. 19(6). 21042110.

[15] Aliviyanti, D., S. Suharjono, C. Retnaningdyah. 2017. Cyanobacteria community dynamics and trophic status of intensive shrimp (Litopenaeus vannamei) farming pond in Situbondo East Java Indonesia. J. Trop. Life Sci. 7(3). 251-257.

[16] Odum, E.P. 1993. Dasar-dasar ekologi, $3^{\text {rd }}$ Ed. In: Samingan, T. (tansl.) Gadjah Mada University Press. Yogyakarta.

[17] Parker, R. 2002. Aquacultural Science, $2^{\text {nd }}$ Ed. Delmar. New York.

[18] Li, Y., G. Xiao, A. Mangott, M. Kent, I. Pirozzi. 2016. Nutrient efficacy of microalgae as aquafeed additives for the adult black tiger prawn, Penaeus monodon. Aquac. Res. 47(11). 3625-3635.

[19] Saad, A., A. Atia. 2014. Review on freshwater blue-green algae (cyanobacteria): occurrence, classification and toxicology. Biosci. Biotechnol. Res. Asia. 11(3). 1319-1325.

[20] Ariadi, H., M. Mahmudi, M. Fadjar. 2019. Correlation between density of vibrio bacteria with Oscillatoria sp. abundance on intensive Litopenaeus vannamei shrimp ponds. Life Sci. 6(2). 114-129.

[21] Junda, M. 2018. development of intensive shrimp farming, Litopenaeus vannamei in land-based ponds: production and management. J. Phys. Conf. Ser. 1028. 1.

[22] Lukwambe, B., L. Qiuqian, J. Wu, D. Zhang, K. Wang, Z. Zheng. 2015. The effects of commercial microbial agents (probiotics) on phytoplankton community structure in intensive white shrimp (Litopenaeus vannamei) aquaculture ponds. Aquac. Int. 23(6). 1443-1455.

[23] Samadan, G. M., Rustadi, Djumanto, Murwantoko. 2018. Production performance of whiteleg shrimp Litopenaeus vannamei at different stocking densities reared in sand ponds using plastic mulch. AACL Bioflux. 11(4). 1213-1221.

[24] Ridlo, A., Subagio. 2013. Pertumbuhan, rasio konversi pakan dan kelulushidupan udang Litopenaeus vannamei yang diberi pakan dengan suplementasi prebiotik fos (fruktooligosakarida). Buletin Oseanografi Marina. 2(4). 1-8.

[25] Sookying, D., D.A. Davis. 2011. Pond production of Pacific white shrimp (Litopenaeus vannamei) fed high levels of soybean meal in various combinations. Aquac. 319(1-2). 141-149.

[26] Shi, F., P. McNabb, L. Rhodes, P. Holland, S. Webb, J. Adamson, A. Immers, R. Gooneratne, J. Holland. 2012. The toxic effects of three dinoflagellate species from the genus Karenia on invertebrate larvae and finfish. N. Z. J. Mar. Freshwater Res. 46(2). 149-165.

[27] Lailiyah, U.S., S Rahardojo, M.G.E. Kristiany, M. Mulyono. 2018. Provinsi Jawa Barat productivity of vannamei shrimp cultivation (Litopenaeus vannamei) super inensive pond in PT. Dewi Laut Aquaculture Garut District. Jurnal Kelautan dan Perikanan Terapan. 1. 1-11.

[28] Gunarto, E.A. Hendrajat. 2008. Budidaya udang vannamei, Litopenaeus vannamei pola semi intensif dengan aplikasi beberapa jenis probiotik komersial. Jurnal Riset Akuakultur. 3(3). 339-349.

[29] Kumar, P. 2015. Survival and growth performance of pacific white shrimp Litopenaeus vannamei (Boone1931) under different stocking densities. IOSR Journal of Agriculture and Veterinary Science Ver. I. 8. 5. 2319-2372.

[30] Kilawati, Y., Y. Maimunah. 2015. Kualitas lingkungan tambak insentif litopenaeus vannamei dalam kaitannya dengan prevalensi penyakit white spot syndrome virus. Res. J. Life Sci. 2(1). 50-59.

[31] Supriatna, Marsoedi, A.M. Hariati, M. Mahmudi. 2017. Dissolved oxygen models in intensive culture of whiteleg shrimp, Litopenaeus vannamei, in East Java, Indonesia. AACL Bioflux. 10(4). 768-778.

[32] Mainassy, M.C. 2015. Pengaruh parameter fisika dan kimia terhadap kehadiran ikan lompa (Thryssa baelama Forsskål) di perairan Pantai Apui Kabupaten Maluku Tengah. Perikanan. 19(2). 61-66.

[33] Jaganmohan, P., L. Kumari. 2018. Assessment of water quality in shrimp ( $L$. vannamei) grow out ponds in selected villages of S.P.S.R Nellore district of Andhra Pradesh, India during winter crop season. Int. J. Fish. Aquat. Stud. 6(3). 260-266.

[34] Tucker, C.S., L.R.D. Abramo. 2008. Managing High $\mathrm{pH}$ in Freshwater Ponds. SRAC Publ. 46(4604). 1-3.

[35] Maicá, P.F., M.R. de Borba, T.G. Martins,W. Wasielesky. 2014. Effect of salinity on performance and body composition of Pacific white shrimp juveniles reared in a 
super-intensive system. R. Bras. Zootec. 43(7). 343-350.

[36] Syukri, M., M. Ilham. 2016. Pengaruh salinitas terhadap sintasan dan pertumbuhan larva udang windu (Penaeus monodon). Jurnal Galung Tropika. 5(2). 8696.

[37] Furtado, P.S., B.R. Campos, F.P. Serra, M. Klosterhoff, L.A. Romano, W. Wasielesky. 2015. Effects of nitrate toxicity in the Pacific white shrimp, Litopenaeus vannamei, reared with biofloc technology (BFT). Aquac. Int. 23(1). 315-327.

[38] Neto, I.A., H. Brandão, P.S. Furtado, W, Wasielesky. 2019. Acute toxicity of nitrate in Litopenaeus vannamei juveniles at low salinity levels. Cienc. Rural. 49(1). 1-9.

[39] Saraswathy, R., M. Muralidhar, P. Ravichandran, A.G. Ponniah, A. Panigrahi, M. Kailasam, A. Nagavel. 2012. Effect of nutrient level on phytoplankton population in zero water exchange shrimp culture farms. Indian J. Fish. 59(2). 115-120.

[40] Lin, Y.C., J.C. Chen. 2003. Acute toxicity of nitrite on Litopenaeus vannamei (Boone) juveniles at different salinity levels. Aquac. 224(4). 193-201.

[41] Romano, N., C. Zeng. 2013. Toxic effects of ammonia, nitrite, and nitrate to decapod crustaceans: a review on factors influencing their toxicity, physiological consequences, and coping mechanisms. Rev. Fish. Sci. 21(1). 1-21.

[42] Sukadi, M. F. 2016. Ketahanan dalam air dan pelepasan nitrogen \& fosfor ke air media dari berbagai pakan ikan air tawar. Jurnal Riset Akuakultur. 5(1). 1. 